\title{
Resistance inducing agents on the biology and probing behaviour of the greenbug in wheat
}

\author{
Rosane Rodrigues Costa Pereira ${ }^{1}$; Jair Campos Moraes²; Ernesto Prado ${ }^{3}$; Ronelza \\ Rodrigues Dacosta ${ }^{4}$ \\ ${ }^{1}$ UFAM/IEAA, R. 29 de agosto - 69800-000 - Humaitá, AM - Brasil. \\ ${ }_{3}^{2} U F L A$ - Depto. de Entomologia, C.P. 3037 - 37200-000 - Lavras, MG - Brasil. \\ ${ }^{3}$ EPAMIG - Unidade Regional Epamig Sul de Minas, C.P. 176 - 37200-000 - Lavras, MG - Brasil. \\ ${ }^{4}$ UNESP/FCA - Programa de Pós-Graduação em Agronomia/Proteção de Plantas, C.P. 237 - 18610-307 - \\ Botucatu, SP - Brasil. \\ *Corresponding author<jcmoraes@ufla.br>
}

\begin{abstract}
The greenbug Schizaphis graminum (Rond.) (Hemiptera: Aphididae) is one of the main pestinsects of wheat (Triticum aestivum, L.). Resistance inducing agents as silicon (Si) and acibenzolar-s-methyl (ASM) can provide some protection against insects and diseases. The effect of Si and/or ASM on the development and probing behaviour of $S$. graminum in wheat plants was evaluated. Wheat plants (cultivar Embrapa 22) were treated with Si (silicic acid at the rate of 1\%) and acibenzolar-S-methyl (ASM) at the rate of $0.5 \%$. The effects of these treatments on greenbugs were analyzed by development parameters, honeydew excretion and probing behavior monitored by Electrical Penetration Graphs (EPG). The development and honeydew experiments consisted of ten replications each and EPG experiment was replicated 25 times. The application of both resistance inducing agents reduced fecundity, prolonged the duration of pre-reproductive period, and decreased honeydew production. Induced resistance was localized mainly at phloem level and caused a strong reduction of phloem sap ingestion, but some effect of ASM at parenchyma/mesophyll level could not be discounted as far fewer aphids reached the sieve elements.
\end{abstract}

Key words: S. graminum, EPG, ASM, silicon, induced resistance

\section{Agentes indutores de resistência na biologia e no comportamento alimentar do pulgão-verde em trigo}

\begin{abstract}
RESUMO: O pulgão-verde Schizaphis graminum (Rond.) (Hemiptera: Aphididae) é um dos principais insetospraga da cultura do trigo (Triticum aestivum, L.). Agentes que induzem resistência como silício e acibenzolars-methyl (ASM) podem fornecer proteção às plantas contra insetos e doenças. Avaliou-se o efeito do silício e/ ou ASM no desenvolvimento e comportamento alimentar de S. graminum em plantas de trigo. Plantas de trigo cultivar Embrapa 22 foram tratadas com silício (ácido silícico a 1\%) e acibenzolar-S-methyl (ASM) a $0.5 \%$. Os parâmetros estudados foram biologia, excreção de boneydew e comportamento alimentar (de prova) monitorado por meio da técnica Electrical Penetration Graphs (EPG). Para o estudo de biologia e excreção de honeydew foram usadas dez repetições e 25 para EPG. A aplicação de agentes indutores de resistência reduziu o número de ninfas, prolongando a duração de período de pré-reprodutivo e o número de gotas de honeydew. O efeito de resistência foi localizado principalmente no floema, com redução de ingestão de seiva elaborada. Palavras-chave: S. graminum, EPG, ASM, silício, resistência induzida
\end{abstract}

\section{Introduction}

The greenbug Schizaphis graminum Rond. (Hemiptera: Aphididae) is abundant in wheat (Triticum aestivum, L.) crops and limits yield through direct damage and transmission of plant viruses (Salvadori and Tonet, 2001). Plant resistance against arthropod pests can provide an efficient method of control.

The use of soluble silicon (Si) for controlling arthropod pests has become increasingly popular with several commercial products present in the market (Tally et al., 1999). Silicon has been reported to increase plant productivity (Melo et al., 2007) and plant resistance against diseases and insects (Costa and Moraes, 2006; Epstein,
1994; Goussain et al., 2005; Marschner, 1995) by intensification of physiological and mechanical barriers (Korndörfer and Lepsch, 2001). There is strong evidence that $\mathrm{Si}$ is effective against sucking insects by acting as a feeding inhibitor that interferes with physiological factors associated with feeding (Gomes et al., 2005).

Acibenzolar-s-methyl (ASM) is the first synthetic chemical developed and marketed that functions by activating plant defence responses. This compound was shown to provide protection to wheat plants by affecting the development and reproduction of S. graminum (Costa and Moraes, 2006).

Stylet penetration or probing behaviour of sucking insects can be studied with Electrical Penetration 
Graphs, EPG (Tjallingii, 1978). The insect is part of an electrical circuit which is closed when the stylets are inserted into the tissue. Changes in resistance to the electrical current and electromotive forces $(\mathrm{emf})$ are recorded, and these changes indicate stylet position inside the plant tissues and biological activities such as stylet movement, salivation and ingestion (Walker and Backus, 2000). Therefore, this technique appears to be adequate to study greenbug probing in plants with induced resistance. The objectives of this work were to study the biology and probing behaviour of S. graminum in wheat plants treated with silicon and ASM.

\section{Material and Methods}

A stock culture of greenbug, originated from aphids collected in Lavras, state state of Minas Gerais, Brazil, was kept on sorghum leaf sections of $10 \mathrm{~cm}$ length placed in the vertical direction and fixed with a disk of Styrofoam within a plastic cup with $25 \mathrm{~mL}$ water to maintain turgor. They were maintained inside acclimatised chambers at $25 \pm 2{ }^{\circ} \mathrm{C}$ and photophase of 12 hours.

Four wheat seeds of the cultivar Embrapa 22 per pot with the capacity for $1 \mathrm{~kg}$ of substrate soil/manure at the ratio 2:1 were planted and were arranged on a bench. Ten days after sowing, thinning was conducted leaving two vigorous plants per pot. Silicon and acibenzolar-Smethyl were applied $20 \mathrm{~d}$ after sowing for all the trials. The application of ASM at a rate of $0.5 \%$ was applied directly to foliage until run off, while the application of $\mathrm{Si}$ (silicic acid at a rate of $1 \%$ ) was done directly on the soil/manure substrate, around the plants, by the application of $50 \mathrm{~mL}$ of solution per pot (equivalent to $1 \mathrm{t} \mathrm{SiO}_{2}$ $\left.\mathrm{ha}^{-1}\right)$. These intact plants were utilized in all the tests.

The experiment was conducted in a greenhouse. Individual clipcages of $0.5 \mathrm{~cm}$ height and $0.8 \mathrm{~cm}$ diameter (Moraes et al., 2005) were attached to leaves, one cage per leaf per plant. Five days after the application of the treatments, two adult females at the beginning of their reproductive period were confined in each cage for one day. Then, the insects were removed with exception of one newborn nymph. When the reproductive period started, the insects were inspected daily and newborn nymphs were removed with aid of a fine brush. Cages were moved to new leaves on the same plant every two days.

The biological parameters observed were: duration of the pre-reproductive, reproductive and post-reproductive periods; number of nymphs; population growth rate and longevity. The method proposed by Wyatt and White (1977) was used to estimate the population growth rate: $r_{m}=0.738\left(\log _{e} M_{d}\right) / d$, where: $r_{m}$ : population growth rate; $\mathrm{M}_{\mathrm{d}}$ : number of nymphs born during the period equal to "d" that starts at first reproduction; $d$ : duration of pre-reproductive period in days.

A completely randomised experimental design with four treatments in a factorial scheme 2 (without $\mathrm{Si}$ and with Si) X 2 (without ASM and with ASM) with ten replicates was used in this bioassay.
Honeydew excretion by aphids is a good indication of ingestion of phloem sap from sieve elements. Experiments were performed in laboratory at $25 \pm 2{ }^{\circ} \mathrm{C}$ and 12 hours photophase ten days after the application of treatments. A 12 hour honeydew clock (Goussain et al., 2005) was used with filter paper impregnated with ninhydrin solution (solution of $3 \mathrm{~mL}$ glacial acetic acid, 10 $\mathrm{ml}$ n-butyl alcohol and $0.3 \mathrm{~g}$ ninhydrin) which stains amino acids in the honeydew (Mittler, 1978). Aphids were starved for one hour and then placed on the abaxial side of a leaf of a treated plant. The honeydew clock was placed $1 \mathrm{~cm}$ below the aphid to collect the excreted honeydew droplets. The parameter evaluated was the number of droplets produced in the $12 \mathrm{~h}$ period. The experimental design was completely randomized with four treatments in a factorial scheme 2 (without $\mathrm{Si}$ and with Si) $\times 2$ (without ASM and with ASM) with ten repetitions.

For the electrical penetration graphs (EPG), plants were placed inside a Faraday cage in the laboratory five days after applying Si and ASM. Aphid feeding behaviour was monitored by means of a Giga 8 EPG (DC system) with electrical resistance of $1 \mathrm{G} \Omega$. A gold wire of 20 diameter and $20 \mathrm{~mm}$ length was attached to the dorsum of each aphid with the aid of silver conductive and water-based paint. Another electrode was inserted in the substrate soil. The circuit was closed as soon as the stylets of the insect penetrate the leaf tissue. Waveforms (voltage variations) were recorded by a computer and analysed using the STYLET 30 software. Recordings lasted eight hours.

Waveforms are associated with stylet position inside the tissues and with biological activities such as stylet movement (waveforms $\mathrm{C}$ and $\mathrm{F}$ ), salivation (waveform $E_{1}$ ) and ingestion (waveform $E_{2}$ ) (Walker and Backus, 2000). The main distinguished waveforms are pathway, xylem and phloem phase. The waveforms are distinguished based on their magnitude, frequency, level of voltage and electrical origin (Tjallingii and Prado, 2001). Many parameters were analysed but only those that provide information relevant to the objectives of the study are presented here. The chosen parameters (Table 3) were those that would be indicative of resistance factors at the parenchyma/mesophyll level that would interfere with the stylets reaching the phloem as well as parameters that would indicate resistance factors in the phloem.

The experimental design was completely randomized with four treatments: 1- control; 2- silicon; 3- ASM and 4- silicon + ASM, with 25 replicates. Data of number of drops and the number of nymphs were transformed into $\sqrt{X+0.5}$ and then submitted to the analysis of variance. Averages were compared through the $\mathrm{F}$ test at the $5 \%$ level of significance. For the EPG experiment, the means of the treatments were analysed using Kruskal-Wallis non-parametric tests, whereas those expressed in percentages were analysed using the Chisquare test; $\rho$ values $<0.05$ were considered to be significant. 


\section{Results and Discussion}

There were no significant interactions for all variables. Significant effects for the application of Si or ASM on the pre-reproductive period and on the number of nymphs only for Si were observed (Table 1). However, no difference for the reproductive and postreproductive periods were observed, as well as for longevity and population growth rate (Table 1), i.e., these variables were not affected by the application of $\mathrm{Si}$ and / or ASM. Similarly, Costa and Moraes (2002) also observed that the application of $\mathrm{Si}$ in sorghum plants did not affect the duration of the reproductive period of $S$. graminum.

The number of nymphs was affected only by the application of Si. Plants that did not receive the inducer produced 27.8 nymphs per female and those that did produced 14.7 nymphs per female, on average. This result is in agreement with that obtained by Costa and Moraes (2006) in which the number of nymphs of $S$. graminum in wheat plants that received the application of Si via soil was four times lower than in control plants (without $\mathrm{Si}$ ). Carvalho et al. (1999) also noted that the production of nymphs of $S$. graminum in genotypes of sorghum submitted to the application of Si was on average $32 \%$ lower in relation to the control.

The application of Si or ASM, individually or in combination strongly reduced the number of honeydew droplets (Table 2). The data indicate a reduction of the phloem sap ingestion by aphids on treated plants. Goussain et al. (2005) also found that the number of honeydew droplets excreted by the greenbug when fed on plants treated with Si was half of that the control. The reduction of the number of honeydew droplets in plants submitted to the application of Si or ASM indicates factors in these plants that restrict the feeding of this sucking insect.

Plants treated with Si, ASM and combination of both reduced the total non-probing time of aphids; in other words, stylets were withdrawn more frequently in treated plants indicating effects of the inducing agents (Table 3, parameters 1 and 2). The number of cell punc- tures and stylet penetration difficulties during pathway did not differ among treatments (Table 3, parameter 3 and 5). Silicon has been reported to strengthen the cell wall (Korndörfer and Lepsch, 2001) but the results obtained here show that the stylets could penetrate cells with similar frequency on treated and untreated plants. Cell penetration is important for non-persistent virus transmission as aphids need to insert the stylets inside cells to inoculate or acquire virus (Pirone and Perry, 2002; Powell, 2005). Consequently, neither Si nor ASM would be expected to prevent non-persistent virus transmission.

The duration of the difficulty of penetration of the stylet in the tissues (Table 3, parameter 6) was higher in treatment with ASM or ASM + Si, when compared to untreated plants. Also a lower proportion of insects reached phloem phase in plants treated with ASM when compared with untreated plants (Table 3, parameter 4). However, the number of probes prior the successful probe and the time to reach phloem phase were similar in all treatments in those aphids that reached the phloem (Table 3, parameter 7 and 8). This result suggests some effect of ASM at parenchyma/ mesophyll level making difficult stylet penetration but, on the other hand, those insects that reached the sieve elements appeared not to encounter impediments. Nothing is known about the distribution of the induced local plant defences and the route followed by the stylets in some aphids could have biased some

Table 2 - Number of honeydew droplets of S. graminum in wheat plants treated with silicon (Si) and/or ASM recorded for $12 \mathrm{~h}$ (average \pm standard error); $\mathrm{n}=10$.

\begin{tabular}{lcc}
\hline \multirow{2}{*}{ Silicon } & \multicolumn{2}{c}{ ASM } \\
\cline { 2 - 3 } & Without & With \\
\hline Without Si & $13.4 \pm 1.5 \mathrm{aA}$ & $4.3 \pm 1.3 \mathrm{aB}$ \\
With Si & $5.0 \pm 1.4 \mathrm{bA}$ & $6.3 \pm 1.2 \mathrm{aA}$ \\
\hline
\end{tabular}

Averages followed by same letter are not different (F test, $p \leq$ 0.05). Capital letters in the rows and lower case letters in the columns.

Table 1 - Pre-reproductive, reproductive and post-reproductive periods, number of nymphs, longevity and population growth rate (average \pm standard error) laid by S. graminum in wheat plants submitted to the application of silicon or ASM in greenhouse; $\mathrm{n}=10$.

\begin{tabular}{lrrrrrr}
\hline \multirow{2}{*}{ Variable } & \multicolumn{2}{c}{ Silicon } & & \multicolumn{2}{c}{ ASM } \\
\cline { 2 - 3 } \cline { 5 - 6 } & \multicolumn{1}{c}{ Without } & With & & Without & With \\
\hline Pre-reproductive period (days) & $7.4 \pm 0.15 \mathrm{~b}$ & $8.1 \pm 0.31 \mathrm{a}$ & & $7.3 \pm 0.15 \mathrm{~b}$ & $8.1 \pm 0.35 \mathrm{a}$ \\
Reproductive period (days) & $14.1 \pm 3.06 \mathrm{a}$ & $11 . \pm \pm 2.73 \mathrm{a}$ & & $11.9 \pm 3.06 \mathrm{a}$ & $13.4 \pm 3.65 \mathrm{a}$ \\
Post-reproductive (days) & $4.1 \pm 1.20 \mathrm{a}$ & $3.4 \pm 1.68 \mathrm{a}$ & & $4.9 \pm 1.20 \mathrm{a}$ & $2.5 \pm 1.16 \mathrm{a}$ \\
Number of nymphs & $27.9 \pm 8.70 \mathrm{a}$ & $14.7 \pm 4.38 \mathrm{~b}$ & & $25.4 \pm 8.70 \mathrm{a}$ & $17.5 \pm 4.37 \mathrm{a}$ \\
Longevity & $25.5 \pm 3.57 \mathrm{a}$ & $22.5 \pm 3.78 \mathrm{a}$ & & $24.1 \pm 3.57 \mathrm{a}$ & $24.1 \pm 3.30 \mathrm{a}$ \\
Population growth rate & $0.3 \pm 0.03 \mathrm{a}$ & $0.2 \pm 0.03 \mathrm{a}$ & & $0.3 \pm 0.03 \mathrm{a}$ & $0.2 \pm 0.03 \mathrm{a}$ \\
\hline
\end{tabular}

Averages followed by same letter, in the rows, are not different (F test, $p \leq 0.05)$. 
Table 3 - Probing behaviour of S. graminum on wheat plants treated or untreated with silicon (Si) and/or acibenzolar-smethyl (ASM) (means \pm standard error). Parameters during $8 \mathrm{~h}$ EPG recording.

\begin{tabular}{|c|c|c|c|c|c|}
\hline \multirow{2}{*}{ Parameter } & \multirow{2}{*}{ Unit } & \multicolumn{4}{|c|}{ Treatment } \\
\hline & & Untreated & $\mathrm{Si}$ & ASM & $\mathrm{Si}+\mathrm{ASM}$ \\
\hline 1. Non-probing & number & $\begin{array}{c}7.5 \pm 0.8 b \\
(n=25)\end{array}$ & $\begin{array}{l}10.8 \pm 1.4 a b \\
(n=25)\end{array}$ & $\begin{array}{l}9.6 \pm 1.5 \mathrm{ab} \\
(\mathrm{n}=25)\end{array}$ & $\begin{array}{l}12.1 \pm 1.4 \mathrm{a} \\
(\mathrm{n}=25)\end{array}$ \\
\hline 2. Total non-probing duration & $\min$ & $\begin{array}{l}56.1 \pm 16.2 b \\
\quad(n=25)\end{array}$ & $\begin{array}{c}174.7 \pm 28.4 \mathrm{a} \\
(\mathrm{n}=25)\end{array}$ & $\begin{array}{l}187.9 \pm 32.4 \mathrm{a} \\
(\mathrm{n}=25)\end{array}$ & $\begin{array}{c}165.9 \pm 27.0 \mathrm{a} \\
(\mathrm{n}=25)\end{array}$ \\
\hline 3. Cell punctures (waveform F) & number & $\begin{array}{l}90.5 \pm 0.0 \mathrm{a} \\
\quad(\mathrm{n}=25)\end{array}$ & $\begin{array}{l}67.2 \pm 10.5 a \\
(n=25)\end{array}$ & $\begin{array}{l}66.6 \pm 11.8 \mathrm{a} \\
(\mathrm{n}=25)\end{array}$ & $\begin{array}{l}81.0 \pm 11.3 a \\
(n=25)\end{array}$ \\
\hline $\begin{array}{l}\text { 4. Percentage of aphids reaching the phloem } \\
\text { phase }(*)\end{array}$ & $\%$ & $\begin{array}{l}96.0 \pm 0.1 \mathrm{a} \\
\quad(\mathrm{n}=25)\end{array}$ & $\begin{array}{l}68.0 \pm 0.1 \mathrm{ab} \\
\quad(\mathrm{n}=25)\end{array}$ & $\begin{array}{l}52.0 \pm 0.1 b \\
(n=25)\end{array}$ & $\begin{array}{l}80.0 \pm 0.1 \mathrm{ab} \\
\quad(\mathrm{n}=25)\end{array}$ \\
\hline 5. Stylet penetration difficulties during pathway & number & $\begin{array}{c}1.8 \pm 0.4 a \\
(n=25)\end{array}$ & $\begin{array}{c}1.7 \pm 0.3 a \\
(n=25)\end{array}$ & $\begin{array}{c}3.2 \pm 0.6 a \\
(n=25)\end{array}$ & $\begin{array}{c}2.9 \pm 0.5 a \\
(n=25)\end{array}$ \\
\hline $\begin{array}{l}\text { 6. Total duration of stylet penetration } \\
\text { difficulties during pathway }\end{array}$ & $\min$ & $\begin{array}{l}51.9 \pm 10.9 b \\
\quad(n=19)\end{array}$ & $\begin{array}{l}108.1 \pm 24.6 \mathrm{ab} \\
(\mathrm{n}=17)\end{array}$ & $\begin{array}{l}128.6 \pm 22.9 \mathrm{a} \\
\quad(\mathrm{n}=20)\end{array}$ & $\begin{array}{c}145.8 \pm 26.3 \mathrm{a} \\
(\mathrm{n}=21)\end{array}$ \\
\hline $\begin{array}{l}\text { 7. Probes prior the successful probe (when } \\
\text { reaching the phloem). (data includes only aphids } \\
\text { that reached phloem phase) }\end{array}$ & number & $\begin{array}{c}5.7 \pm 0.8 \mathrm{a} \\
(\mathrm{n}=24)\end{array}$ & $\begin{array}{c}8.7 \pm 1.8 a \\
(n=17)\end{array}$ & $\begin{array}{l}5.8 \pm 1.4 a \\
(n=13)\end{array}$ & $\begin{array}{l}7.8 \pm 0.9 a \\
(n=20)\end{array}$ \\
\hline $\begin{array}{l}\text { 8. Time to first phloem phase in the successful } \\
\text { probe (when reaching the phloem) }\end{array}$ & $\min$ & $\begin{array}{l}20.7 \pm 2.6 \mathrm{a} \\
\quad(\mathrm{n}=24)\end{array}$ & $\begin{array}{l}20.9 \pm 5.5 a \\
\quad(n=17)\end{array}$ & $\begin{array}{c}24.5 \pm 4.7 \mathrm{a} \\
\quad(\mathrm{n}=13)\end{array}$ & $\begin{array}{l}18.4 \pm 2.5 \mathrm{a} \\
\quad(\mathrm{n}=20)\end{array}$ \\
\hline $\begin{array}{l}\text { 9. Total duration of phloem phase (only aphids } \\
\text { showing this phase) }\end{array}$ & $\min$ & $\begin{array}{l}219.5 \quad 23.1 \mathrm{a} \\
\quad(\mathrm{n}=24)\end{array}$ & $\begin{array}{l}57.1 \pm 20.7 b \\
\quad(n=17)\end{array}$ & $\begin{array}{l}79.1 \pm 21.6 b \\
(n=13)\end{array}$ & $\begin{array}{l}46.2 \pm 13.1 b \\
(n=20)\end{array}$ \\
\hline $\begin{array}{l}\text { 10. Total duration of phloem salivation (only } \\
\text { aphids showing this event) (waveform } E_{1} \text { ) }\end{array}$ & $\min$ & $\begin{array}{l}16.0 \pm 4.0 a \\
(n=24)\end{array}$ & $\begin{array}{c}8.0 \pm 1.9 a \\
(n=17)\end{array}$ & $\begin{array}{c}8.4 \pm 1.8 \text { a } \\
(n=13)\end{array}$ & $\begin{array}{l}12.0 \pm 2.8 \mathrm{a} \\
(\mathrm{n}=20)\end{array}$ \\
\hline $\begin{array}{l}\text { 11. Total duration of sap ingestion (only aphids } \\
\text { showing this event) (waveform } \mathrm{E}_{2} \text { ) }\end{array}$ & $\min$ & $\begin{array}{c}222.2 \pm 23.8 \mathrm{a} \\
(\mathrm{n}=24)\end{array}$ & $\begin{array}{c}92.2 \pm 33.2 \mathrm{ab} \\
(\mathrm{n}=17)\end{array}$ & $\begin{array}{l}76.5 \pm 21.9 b \\
(n=13)\end{array}$ & $\begin{array}{c}42.7 \pm 15.2 b \\
(n=20)\end{array}$ \\
\hline
\end{tabular}

Letters after means denote differences within rows (Kruskal-Wallis test followed by multiple comparisons, $\alpha=0.05) . *$ Differences according to the Chi-square test $(\alpha=0.05)$.

of these defences. Correa et al. (2005) also found negative effects of ASM on the behavior of Bemisia tabaci, biotype B (Genn.) (Hemiptera: Aleyrodidade) in cucumber plants.

Parameters associated with phloem promoted a reduction of the total duration of the phloem phase (Table 3 , parameter 9), that appears to be a result of a decrease in sap ingestion time (Table 3, parameter 11) in the treated plants. Salivation inside sieve elements was not affected by the treatments (Table 3, parameter 10). These results indicate that $\mathrm{Si}$ and ASM induced resistance in the plant are mainly localised at phloem level and reduce aphid feeding. This is in according to the reduced number of honeydew droplets obtained in treated plants.

The insects that successfully reached phloem phase did it in the same time on treated and on control plants. However, the probing duration was reduced by the application of the inducers. Similarly, Goussain et al. (2005) found that the time spent by S. graminum to reach the phloem in wheat plants was similar between plants treated with Si and untreated plants and also, as in this study, there was no effect of the $\mathrm{Si}$ application on the biology of these aphids. These results suggest that plants fertilized with Si had some secondary compost added in sap.
The application of Si reduced the number of nymphs, the number of honeydew droplets and the total duration of phloem ingestion in treated plants. Thus, Si may have acted as inducing substances for the defense of attacked plants, reducing the probing time, and consequently, the greenbug fertility. Generally, the use of Si or ASM provided resistance to wheat plant against the attack by greenbug.

\section{Conclusions}

Development and fecundity of S. graminum were affected by the application de Si on wheat, but the ASM only affected the pre-reproductive period of the aphid. The effect was localized mainly at phloem level with a strong reduction of phloem sap ingestion.

\section{Acknowledgements}

To CNPq and CAPES for scholarships and FAPEMIG for scholarships and financial support.

\section{References}

Carvalho, S.P.; Moraes, J.C.; Carvalho J.G. 1999. Silica effect on the resistance of Sorghum bicolor (L.) Moench to the greenbug Schizaphis graminum (Rond.) (Homoptera: Aphididae). Anais da Sociedade Entomológica do Brasil 28: 505-510. (in Portuguese, with abstract in English). 
Correa, R.S.B.; Moraes, J.C.; Auad A.M.; Carvalho, G.A. 2005. Silicon and Acibenzolar-S-Methyl as Resistance Inducers in Cucumber, against the Whitefly Bemisia tabaci (Gennadius) (Hemiptera: Aleyrodidae) Biotype B. Neotropical Entomology 34: 429-433.

Costa, R.R.; Moraes, J.C. 2002. Resistance induced in Sorghum by sodium silicate and initial infestation by the Green aphid Schizaphis graminum. Ecossistema 27: 37-39. (in Portuguese, with abstract in English).

Costa, R.R.; Moraes, J.C. 2006. Effects of silicon and of acibenzolars-methyl on Schizaphis graminum (Rondani) (Hemiptera: Aphididae) in wheat plants. Neotropical Entomology 5: 834839. (in Portuguese, with abstract in English).

Epstein, E. 1994. The anomaly of silicon in plant biology. Proceedings of the National Academy of Science 91: 11-17.

Gomes, F.B.; Moraes, J.C.; Santos, C.D.; Goussain, M.M. 2005. Resistance induction in wheat plants by silicon and aphids. Scientia Agricola 62: 547-551.

Goussain, M.M.; Moraes, J.C.; Prado, E. 2005. Effect of silicon applied to wheat plants on the biology and probing behaviour of the greenbug Schizaphis graminum (Rond.) (Hemiptera: Aphididae). Neotropical Entomology 34: 807-813. (in Portuguese, with abstract in English).

Korndörfer, G.H.; Lepsch, I. 2001. Effect of silicon on plant growth and yeld. p.133-147. In: Datnoff, L.E.; Snyder, G.H.; Korndorfer, G.H., eds. Silicon in agriculture. Elsevier Science, Amsterdam, NL.

Marschner, H. 1995. Mineral Nutrition of Higher Plants. Academic Press, London, UK.

Melo, S.P.; Monteiro, F.A.; Manfredini, D. 2007. Silicate and phosphate combinations for marandu palisadegrass growing on an oxisol. Scientia Agricola 64: 275-281.

Moraes, J.C.; Goussain, M.M.; Carvalho, G.A.; Costa, R.R. 2005. Feeding non-preference of the corn leaf aphid Rhopalosiphum maidis (Fitch, 1856) (Hemiptera: Aphididae) to corn plants (Zea mays L.) treated with silicon. Ciência e Agrotecnologia 29: 761766.
Pirone, T.P.; Perry, K.L. 2002. Aphids: non-persistent transmission. Advanced Botanical Reviews 36: 1-19.

Powell, G. 2005. Intracellular salivation is the aphid activity associated with inoculation of nonpersistently transmitted viruses. Journal of General Virology 86: 469-472.

Salvadori, J.R.; Tonet, G.E.L. 2001. Integrated Management of Aphids in Wheat. EMBRAPA-CNPT, Passo Fundo, RS, Brazil. (in Portuguese).

Tjallingii, W.F. 1978. Electronic recording of penetrations behavior by aphids. Entomologia Experimentalis Applicata 24: 521-530.

Tjallingii, W.F.; Prado, E. 2001. Analysis of circulative transmission by electrical penetration graphs. In: Harris, K.F.; Smith, O.P.; Duffus, J.E., eds. Virus-insect-plant interactions. Academic Press, London, UK.

Wyatt, I.J.; White, P.F. 1977. Simple estimation of intrinsic increase rates for aphids and tetranychid mites. Journal of Applied Ecology 14: 757-766.

Tally, A.; Oostendorp, M.; Lawton, K.; Staub, T.; Bassi, B. 1999. Commercial development of elicitors of induced resistance to pathogens. p. 357-369. In: Agrawal, A.A.; Tuzun, S.; Bent, E., eds. Induced plant defences against pathogens and herbivores. APS Press, St. Paul, MN, USA.

Walker, G.P.; Backus, E.A. 2000. Principles and Applications of Electronic Monitoring and Other Techniques in the Study of Homopteran Feeding Behavior. Thomas Say Publications in Entomology, Lanham, MD, USA.

Received November 13, 2008

Accepted April 30, 2010 